\title{
Distribution of icthyoplankton in the sinu river, Colombia
}

\begin{abstract}
Taking into account that recently the study of icthyoplankton has become important as an indicator of the reproductive performance of the reofilics fishes, the present investigation studies their distribution in the Sinú River, Colombia, according to the hydraulic variables (area, speed, depth and open surface). 18 samplings were carried out between the years 2001 and 2003, utilizing flow meters, spindles and procedures for the quantification of larvae; it is proposed that a methodology to estimate the total load of icthyoplankton considering that the distribution follows the same pattern as the distribution of the average speed of the river; the results indicate that the greater load of icthyoplankton pass by the areas of lesser speed. The estimations of the quantity of icthyoplankton are overestimated when considering an even distribution; hence it is suggested that the proposed method be utilized, in order to quantify the estimation of icthyoplankton that passes by the principal canal of a river.
\end{abstract}

Keywords: reofilics fishes, ictiología, hydraulic variables, transport of larvae, tropical rivers
Volume 3 Issue 4 - 2018

\author{
Teobaldis Mercado Fernández,' Eduardo \\ Kerguelén Durango, ${ }^{2}$ Victor Atencio García ${ }^{2}$ \\ 'Professor, University of Córdoba, Hidrociencias, Colombia \\ ${ }^{2}$ Fish Research Center, Universidad de Córdoba, Colombia
}

Correspondence: Teobaldis Mercado Fernández, Professor University of Córdoba, PhD, Hidrociencias, Carrera 6a \# 76 103, Montería, Córdoba, Colombia,

Email tmercado@correo.unicordoba.edu.co

Received: June 18,2018| Published: August 08, 2018

\section{Introduction}

The Sinu River originates from the Nudo de Paramillo (Colombia), travels across $380 \mathrm{Km}$ before flowing into the Caribbean Sea of Colombia, its basin has an area of $15.600 \mathrm{Km}^{2}$ and is $266 \mathrm{Km}^{2}$ from the mouth a hydroelectric power station was constructed. The more important commercial fish from the Colombian rivers are the known reofilics fishes among which stand out carácidos of the genus Prochilodus, Brycon, Leporinus and silúridos such as Pseudoplatystoma, Sorubim, Pimelodus, Brachyplatystoma, among others. Those fish abandon the swamps and migrate upstream in the dry period in order to secure areas of maturity; in the Sinú river this event generally occurs between October and February of each year. Subsequently during the rainy period (April-October) they reproduce, considering the months from April to July as those of greater reproductive activity. Then from spawning they return again to the swamps or flood plains where they recuperate and initiate a new reproductive cycle. One of the exceptional characteristics of the reofilics fishes is their reproduction (courting, mating and spawning) occur in the principal canal of the rivers; as well as the incubation and hatching of the larvae, those products called icthyoplankton are transported to the flood plains (swamps) when they are soon ready to initiate exogenous feeding. ${ }^{1-3}$

The study of eggs and fish larvae that are transported by the river has gained attention because it offers information about the ecology, biology and systematic of these species. ${ }^{4}$ It allows for the recognition of embryos and fish larvae in natural environments. ${ }^{2}$ it allows for the identification of the hatching areas, reproductive period and their quantitative estimation, it is an indicator of the reproductive performance of reofilics fishes., ${ }^{5,6}$ In general, studies about icthyoplankton, in South American rivers (Amazona, San Francisco, Panama, Orinoco, Uruguay, Magdalena and Sinu, among others) are focused principally on the description of eggs and larvae..$^{2-10}$ Some to the determination of areas and seasons for hatching ${ }^{3-11}$ and the quantitative estimation of icthyoplankton as an indicator of reproductive performance of the reofilics fishes has recently become important, in order to monitor the effects of the disturbances caused in the rivers taken over by antropic action.

Studying the variables that define how icthyoplankton is transported in the rivers, in particular how is their distribution in the section of the river ${ }^{5-12}$ will allow advancements in the definition of a model of quantitative estimation that considers its distribution, as well as allow for a better way of selecting the sites for sample collection of icthyoplankton for their study. One of the characteristics of the plankton is that its transportation capacity is limited and therefore is defined by the movement of water; in a river the hydraulic variables that define the characteristics of the movement and therefore of the icthyoplankton. Araujo Lima et al., ${ }^{12}$ studied the transport of fish larvae in the Amazon River and found that icthyoplankton of Characiformes and Siluriformes is more abundant near the river banks and they associated it with a strategy to facilitate its dispersion to the flood plains. In the Sinu River Atencio et al., ${ }^{3}$ found that the distribution of the larvae was not even in the section of the river and reported that in the margin of lesser speed more icthyoplankton was collected than in the other. For which the objective of this study was to know the distribution of icthyoplankton according to the hydraulic variables and define a model to estimate the icthyoplankton in the section of the river.

\section{Materials and methods}

In the lower part of the Sinu river, to the higher part of Cotocá Abajo (Córdoba, Colombia.) $40 \mathrm{Km}$ from its mouth in the Caribbean Sea (Figure 1), 18 samples were taken in 2001 (16, 23/jun, 7,21, 28/ July, 4, 16, 25/august, 1, 8, 15 21/sep) and 6 samples in 2003 (14, $21,28 /$ jun, $5,19 / \mathrm{July}, 2 / \mathrm{sep}$ ) in order to evaluate the distribution of icthyoplankton according to the hydraulic variables of the river: area of section and total subsection $\left(\mathrm{m}^{2}\right)$, volume per time $\left(\mathrm{m}^{3} / \mathrm{s}\right)$ of the subsection and section total, open surface $(\mathrm{m})$, vertical depth $(\mathrm{m})$ and speed $(\mathrm{m} / \mathrm{s})$ on the surface, at $20 \%$ and $80 \%$ of each depth of the verticals every $8 \mathrm{~m}$ from the right margin to the left. The open surface of the river in the site of study oscillated between 132 and $140 \mathrm{~m}$, 
which is why the number of verticals for sampling oscillated between 16 and 17 (Figure 1). For the measurement of the speed and depth in each vertical section of the river a flow meter was utilized (A.OTT Kempten, C31-00, Alemania) with a propeller (2-38798, Alemania), flow meter (A.OTT Kemptem, Typ 12.400, Alemania) and a spindle (65645PKS, Alemania). The speed (V) was estimated through the equation 1:

$$
V=0,51 \times N R+0,05
$$

Where $V$ is the speed of the flow $(\mathrm{m} / \mathrm{s})$ and $N R$ is the number of revolutions of the propeller in 50 seconds.

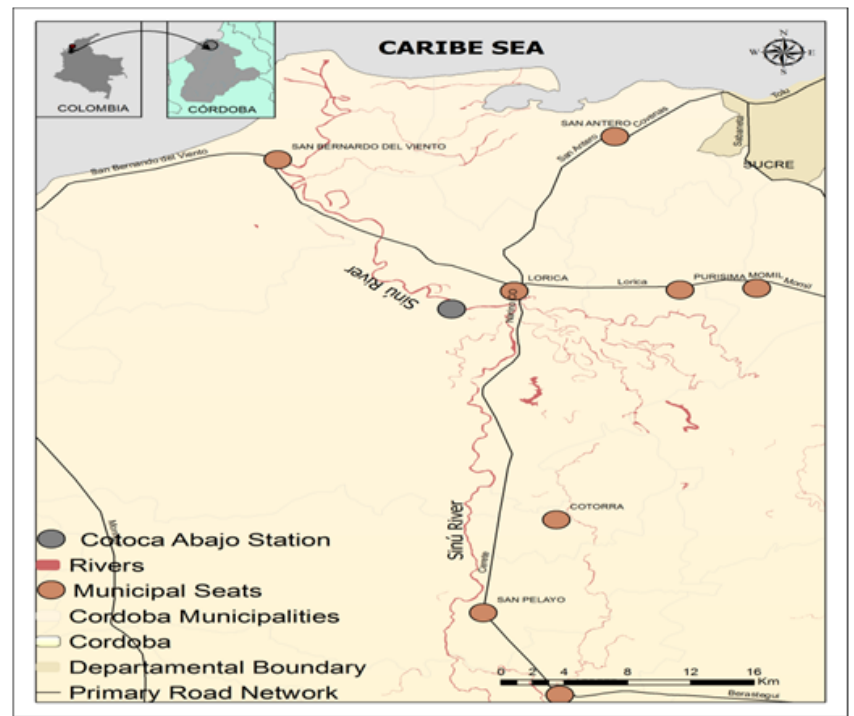

Figure I Study area.

The icthyoplankton was collected with a planktonic net of $0.5 \mathrm{~m}$ in diameter and $0.2 \mathrm{~mm}$ mesh holes, accompanied by a device that would open to the depth indicated and then in a minute would close. The icthyoplankton collected, during this time, was transferred to a transparent $1000 \mathrm{~mL}$ polypropylene container, it was labeled for its subsequent count and identification in the Centro de Investigación Piscícola de la Universidad de Córdoba CINPIC, Colombia, with the help of stereoscope (Carl Zeiss, Stemi 2000c, Alemania), microscope (Carl Zeiss, Axiostar plus, Alemania) and an image analyzer (Carl Zeiss, Axiovision 4, Alemania). For the identification of the icthyoplankton the codes described by Nakatani et al., ${ }^{3},{ }^{4}$ were used.

The load or total density of icthyoplankton in the hydraulic section of the river was estimated with equation 2 , which considers that its distribution follows the same behavior of the speed in the river and the duration of the event an average time of 8 hours a day.

$$
N=\sum_{i}^{n} \frac{Q S_{i} \times C I M R_{i}}{Q_{\text {red }_{i}}}
$$

Where $N$ is the total load of icthyoplankton in the river (individuals/min);

$Q S_{i}$, the volume per time of the subsection $\mathrm{I}\left(\mathrm{m}^{3} / \mathrm{s}\right)$;

$C I M R_{i}$, the load of icthyoplankton from the trap in the subsection $\mathrm{i}$ - nth (individuals/min);
$Q_{\text {red }_{i}}$, the volume per time of the sampling red in the subsection $\mathrm{i}\left(\mathrm{m}^{3} / \mathrm{s}\right)$ and

$n$ the number of subsections.

The load of icthyoplankton in the average trap in a subsection ( CMIR ) depends on the average sample load in the vertical ( CIMV ), which was estimated following the hydraulic distribution of the average speed utilizing equation $3 .{ }^{13,14}$ The load for the first and last subsection is equal to $2 / 3$ of the average loads and their respective verticals; the load for the second to the antepenultimate subsections is equal to the average of the average loads of its adjacent verticals.

$$
C I M V=\frac{C I_{\text {sup }}+3 \times C I_{0,2}+C I_{0,8}}{5}
$$

Where CIMV is the average load of icthyoplankton in each vertical; (individuals/day);

$C I_{\text {sup }}$, the load of simple icthyoplankton on the surface of each vertical;

$C I_{0,2}$, the load of simple icthyoplankton to $20 \%$ of depth in each vertical and

$C I_{0,8}$ the load of sample icthyoplankton $80 \%$ of the depth of each vertical.

\section{Results}

16 larvae states were identified from 13 species of fish, pertaining to eight families of the Characiformes and Siluriformes orders (Table 1) (Figure 2). In the section of the river the distribution of icthyoplankton was not even and was inversely correlated to the speed of the river for which the greater density of icthyoplankton was registered in the left margin where the lesser speeds were measured $(\mathrm{P}>0.05)$ (Figure $3 \& 4)$. In Figure 3 it is observed that the greater speeds are found between the surface and $20 \%$ of the vertical depth, with the tendency to diminish towards the left margin. Figure 4 shows that the load of icthyoplankton is greater towards the right margin, in which the lesser speeds of the river presented themselves. Table 2 presents the estimation of the load or total density of icthyoplankton, in one of the samples (28 of July), utilizing the proposed equations for this study (equations 2 and 3), and in Table 3 the same estimation using equation 4 , which considers the even distribution in the main section of the river.

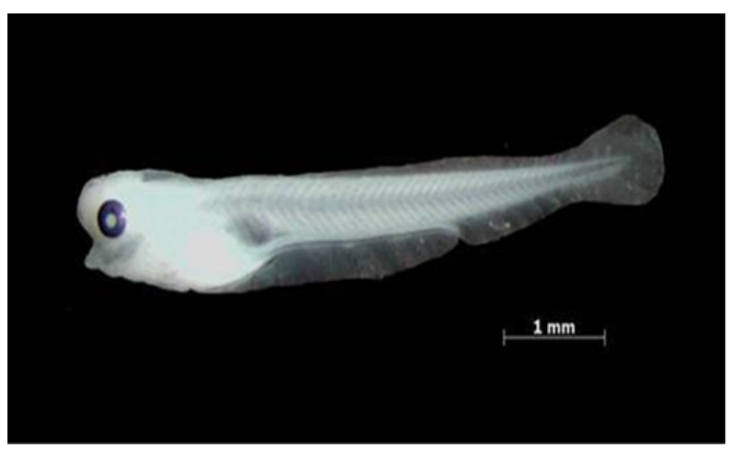

Figure 2 Bocachico larvae (Prochilodus magdalenae). 


$$
N=\frac{Q_{\text {rio }} \times n}{Q_{\text {red }}}
$$

Where $N$ is the load of icthyoplankton in the river (individuals/ $\min )$;

$Q_{\text {rio }}$, the volume per time of the river $\left(\mathrm{m}^{3} / \mathrm{s}\right)$;

$n$, the average number of individuals in the sampling net (individuals/min) y $Q_{\text {red }}$ the volume per time in the icthyoplankton net $\left(\mathrm{m}^{3} / \mathrm{s}\right)$. One can observe that the estimation with equation 4 is 3.2 times greater compared to the proposed method (equations 2 and 3), which indicate that the estimation with equation 4 generates an overestimation of the load of icthyoplankton and reproductive performance of the reofilics fishes that pass through the section of the river, due to the fact that only a vertical superficial in one of the banks is being sampled.
Table I Identification of icthyoplankton collected in the Sinú River to the height of Cotocá Abajo (Córdoba, Colombia)

\begin{tabular}{lll}
\hline Orders & Family & Specie \\
\hline & Prochilodontidae & Prochilodus magdalenae \\
& Anostomidae & Leporinus muyscorum \\
& Curimatidae & Cyphocharax magdalenae \\
Characiformes & Characidae & Brycon sinuensis \\
& & Roeboides sp \\
& & Nanocheirodon insignis Astyanas sp \\
& & Gephyrocharax sinuensis \\
Siluriformes & Cetopsidae & Sorubim cuspicaudus Pimelodus sp \\
& Pseudopimelodidae & Pseudopimelodus bufonius \\
& Heptapteridae & Rhamdia sp
\end{tabular}

Table 2 Estimation of the load of icthyoplankton in the Lower Sinú, Cotocá Abajo, Córdoba, Colombia. (28 July of 200I)

\begin{tabular}{|c|c|c|c|c|c|c|c|c|c|c|}
\hline$D(m)$ & PV (m) & $V V(m)$ & $\begin{array}{l}\text { VMV } \\
(\mathrm{m})\end{array}$ & $\begin{array}{l}\text { VMS } \\
(\mathrm{m})\end{array}$ & AS $\left(m^{2}\right)$ & Qs $\left(m^{3} / s\right)$ & $\begin{array}{l}\mathrm{Cl} \text { (ind/ } \\
\mathrm{min} \text { ) }\end{array}$ & $\begin{array}{l}\text { CIMV (ind/ } \\
\text { min) }\end{array}$ & $\begin{array}{l}\text { CIMR (ind/ } \\
\text { min) }\end{array}$ & $\begin{array}{l}\text { CIMS (ind/ } \\
\text { day) }\end{array}$ \\
\hline \multirow[t]{3}{*}{8} & 3,68 & 0,50 & 0,36 & 0,24 & $\mid 4,72$ & 3,48 & 25 & 22 & 14 & 518180 \\
\hline & & 0,39 & & & & & 23 & & & \\
\hline & & 0,32 & & & & & 14 & & & \\
\hline \multirow[t]{3}{*}{16} & 4,58 & 0,96 & 0,82 & 0,59 & 33,04 & $19,4 \mid$ & 16 & 34 & 28 & $226|56|$ \\
\hline & & 0,95 & & & & & 43 & & & \\
\hline & & 0,69 & & & & & 27 & & & \\
\hline \multirow[t]{3}{*}{24} & 4,95 & 0,99 & 0,80 & 0,81 & 38,12 & 30,88 & 53 & 30 & 32 & 3019314 \\
\hline & & 0,96 & & & & & 24 & & & \\
\hline & & 0,64 & & & & & 27 & & & \\
\hline \multirow[t]{3}{*}{32} & 4,95 & $\mathrm{I}, \mathrm{II}$ & 0,95 & 0,88 & 39,60 & 34,65 & 33 & 19 & 25 & 2381445 \\
\hline & & $\mathrm{I}, \mathrm{II}$ & & & & & 14 & & & \\
\hline & & 0,79 & & & & & 19 & & & \\
\hline \multirow[t]{3}{*}{40} & 4,85 & 1,18 & 0,99 & 0,97 & 39,20 & 37,93 & 37 & 20 & 20 & 1878246 \\
\hline & & $I, I I$ & & & & & 13 & & & \\
\hline & & 0,86 & & & & & 26 & & & \\
\hline \multirow[t]{3}{*}{48} & 4,78 & 1,19 & 1,00 & 0,99 & 38,52 & 38,23 & 7 & 14 & 17 & 1638498 \\
\hline & & 1,16 & & & & & 17 & & & \\
\hline & & 0,84 & & & & & 14 & & & \\
\hline \multirow[t]{3}{*}{56} & 4,62 & $|, 3|$ & 1,03 & $\mathrm{I}, 0 \mathrm{I}$ & 37,60 & 38,07 & 16 & 50 & 32 & $294 \mid 360$ \\
\hline & & 1,23 & & & & & 71 & & & \\
\hline & & 0,82 & & & & & 19 & & & \\
\hline \multirow[t]{3}{*}{64} & 4,72 & $\mathrm{I}, 23$ & 1,01 & 1,02 & 37,36 & 38,01 & 0 & 0 & 25 & 2265004 \\
\hline & & 1,18 & & & & & 0 & & & \\
\hline & & 0,84 & & & & & 0 & & & \\
\hline \multirow[t]{2}{*}{72} & 4,22 & $\mathrm{I}, 27$ & 1,05 & $\mathrm{I}, 03$ & 35,76 & 36,74 & 13 & 8 & 4 & 349678 \\
\hline & & 1,16 & & & & & 4 & & & \\
\hline
\end{tabular}




\begin{tabular}{|c|c|c|c|c|c|c|c|c|c|c|}
\hline$D(m)$ & PV (m) & VV (m) & $\begin{array}{l}\text { VMV } \\
(\mathrm{m})\end{array}$ & $\begin{array}{l}\text { VMS } \\
(\mathrm{m})\end{array}$ & AS $\left(m^{2}\right)$ & Qs $\left(m^{3} / s\right)$ & $\begin{array}{l}\mathrm{Cl} \text { (ind/ } \\
\mathrm{min} \text { ) }\end{array}$ & $\begin{array}{l}\text { CIMV (ind/ } \\
\text { min) }\end{array}$ & $\begin{array}{l}\text { CIMR (ind/ } \\
\text { min) }\end{array}$ & $\begin{array}{l}\text { CIMS (ind/ } \\
\text { day) }\end{array}$ \\
\hline & & 0,93 & & & & & 15 & & & \\
\hline \multirow[t]{3}{*}{80} & 4,42 & 1,06 & 0,94 & 0,99 & 34,56 & 34,21 & 0 & 0 & 4 & 337943 \\
\hline & & $\mathrm{I}, \mathrm{II}$ & & & & & 0 & & & \\
\hline & & 0,76 & & & & & 0 & & & \\
\hline \multirow[t]{3}{*}{88} & 3,82 & $\mathrm{I}, 15$ & 0,90 & 0,92 & 32,96 & 30,24 & 15 & 16 & 8 & 660711 \\
\hline & & 1,13 & & & & & 16 & & & \\
\hline & & 0,67 & & & & & 19 & & & \\
\hline \multirow[t]{3}{*}{96} & 3,9 & 1,13 & 0,91 & 0,90 & 30,88 & 27,87 & 0 & 0 & 8 & 619015 \\
\hline & & $\mathrm{I}, 14$ & & & & & 0 & & & \\
\hline & & 0,67 & & & & & 0 & & & \\
\hline \multirow[t]{3}{*}{104} & 4,08 & 1,13 & 0,94 & 0,92 & 31,92 & 29,37 & 26 & 30 & 15 & | I7048| \\
\hline & & $\mathrm{I}, 14$ & & & & & 31 & & & \\
\hline & & 0,73 & & & & & 31 & & & \\
\hline \multirow[t]{3}{*}{112} & 4,18 & 1,17 & I,07 & 1,00 & 33,04 & 33,04 & 21 & 52 & 41 & 3319649 \\
\hline & & $|, 2|$ & & & & & 65 & & & \\
\hline & & 0,92 & & & & & 45 & & & \\
\hline \multirow[t]{3}{*}{120} & 4,08 & 0,8 & 0,75 & 0,91 & 33,04 & 29,90 & 84 & 102 & 77 & 6235448 \\
\hline & & 0,86 & & & & & 108 & & & \\
\hline & & 0,63 & & & & & 103 & & & \\
\hline \multirow[t]{3}{*}{128} & 3,98 & 0,61 & 0,57 & 0,66 & 32,24 & 21,20 & 105 & 130 & 116 & 9158229 \\
\hline & & 0,62 & & & & & 149 & & & \\
\hline & & 0,52 & & & & & 99 & & & \\
\hline \multirow[t]{3}{*}{132} & 3,48 & 0,99 & 0,71 & 0,64 & 14,92 & 9,55 & 140 & 28 & 79 & 2885065 \\
\hline & & 0,76 & & & & & 0 & & & \\
\hline & & 0,66 & & & & & 0 & & & \\
\hline 134 & & & & 0,47 & 3,48 & I,65 & & & 19 & 158802 \\
\hline
\end{tabular}

Where $\mathrm{PV}=$ Vertical depth, $\mathrm{VV}=$ Velocity in the vertical, $\mathrm{VMV}=$ Average velocity in the vertical, $\mathrm{VMS}=$ Average velocity in the subsection, $\mathrm{AS}=\mathrm{Area}$ of the subsection, $\mathrm{QS}=$ Volume of the subsection, $\mathrm{CIMV}=$ Average load of icthyoplankton in the vertical; CIMR = Average load of icthyoplankton media in the net of the subsection; CIMS = Average load of icthyoplankton in the subsection of the river).

Table 3 Estimation with equation 4 of icthyoplankton in the Sinu river (Cotocá Abajo, Córdoba, Colombia)

\begin{tabular}{llllll}
\hline Hora & $\mathrm{Cl}($ ind $/ \mathrm{min})$ & $\mathrm{CIM}($ ind $/ \mathrm{min})$ & Qred $\left(\mathrm{m}^{3} / \mathrm{s}\right)$ & Qrio $\left(\mathrm{m}^{3} / \mathrm{s}\right)$ & $\mathrm{N}($ ind $/ \mathrm{dí})$ \\
\hline $07+00$ & 27 & 27 & 0,04712 & 494,43 & 135.989 .236 \\
$12+00$ & 25 & & & & \\
$18+00$ & 29 & & & & \\
\hline
\end{tabular}




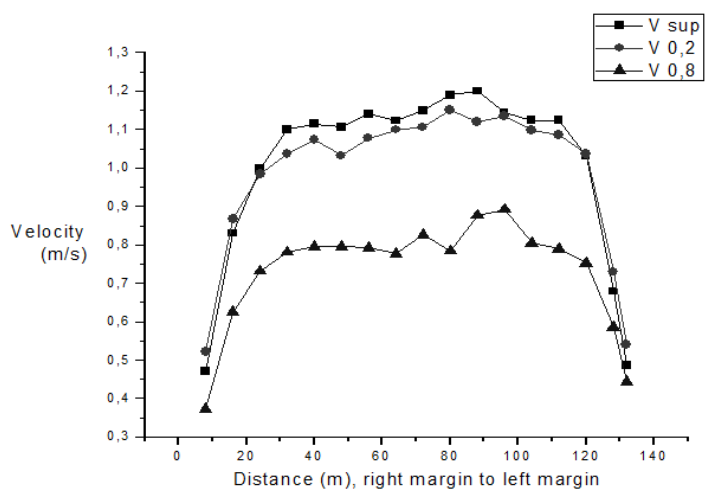

Figure 3 Distribution of average speed $(n=18)$ in the Sinú river to the height of Cotocá Abajo, Colombia.

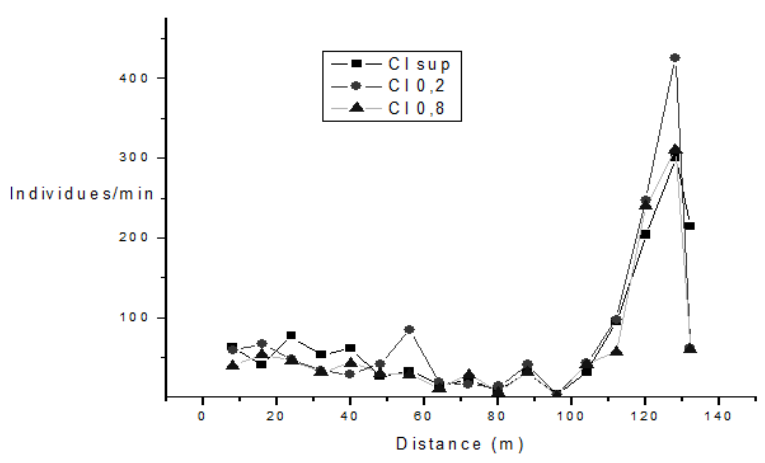

Figure 4 Distribution of accumulated load of icthyoplankton in the Sinú river, Colombia.

\section{Discussion}

During the study 16 larva states of fish, were captured and identified, in a state of pre-flexion between 40 and 66 hours postfertilization, that is $22.5 \%$ of the icthyofauna ( 71 species of fish) that have been reported in the Sinú river by Mójica. ${ }^{15}$ All the species collected pertained to the orders Characiformes and Siluriformes; which according to Mojica, ${ }^{15}$ gather approximately $80 \%$ of the fish registered in the Colombian basins. Of the 16 species of larvae, six are reofilics fishes (Prochilodus magdalenae, Brycon sinuenis, Sorubim cuspicaudus, Leporinus muyscorum, Rhamdia $s p$ and Pimelodus $s p$ ). The Prochilodus magdalenae larvae were the most abundant in the samplings $(67.6 \%)$, coinciding with the distinction of being the principal fish species in the Colombian and Peruvian rivers; ${ }^{16-18}$ although larva of other species, also reofilics and of fishing interest, such as Brycon sinuensis (1.1\%), Sorubim cuspicaudus $(0.8 \%)$ and Pimelodus $s p(1.4 \%)$ are present, they can be considered evidence of the decline of these species seeing that the sampling as much as in 2001 as those in 2003, were realized in the rainy period (AprilSeptember), the season during which reofilics fishes reproduce. ${ }^{5}$ One of the most unusual features of reofilics fishes is that their life cycle is associated as much with the rivers where they reproduce and the swamps (flood plains) where they feed and grow; which is why their eggs and larvae are transported by the principal canal of the river to the swamps.

On considering hydraulic variables such as depth, total section of the canal, volume per time and speed in the Sinu river, it was observed that this ultimate variable is that which most affects the distribution of icthyoplankton. In the Sinú river, the speeds of the right and left margin are different and are related to the process of sedimentation (lesser velocity) and erosion (greater velocity). The greater loads of icthyoplankton were observed in the areas of lesser speeds (margins); that is to say, the greater loads of icthyoplankton travel through the river banks. Araujo-Lima et al., ${ }^{12}$ pointed out that the greater larvae density of Characiformes, in the Amazon river near to the Manaos (Brasil), passed near to the river bank.

The water that runs through the river, located on the rotating Earth, suffers the effects of the Coriolis force towards one of its sides. Thus the erosion is generally greater in one of the banks; in the right bank of the Northern hemisphere, ${ }^{19}$ as the Sinu River flows in the direction of the equator towards the North Pole, the Coriolis Force tends to displace it towards the right margin, increasing its speed, causing the icthyoplankton to orient itself towards the lesser speed margin (left). Although it is also probable that the greater larvae density in one of the margins could be influenced by the river margin in which the spawning of these species took place. De Lafontaine ${ }^{20}$ investigated the distribution and abundance of icthyoplankton in the estuary of the Manicouagan River (Canada) and pointed out that the distribution of icthyoplankton depends principally on the spawning areas and estuarine circulation.

When the quantification of icthyoplankton is estimated considering an even distribution (equation 4), it results in an overestimation of the quantity of icthyoplankton that passes through the section, because as it is demonstrated in this study of icthyoplankton, given its limited capacity of movement, its distribution is affected by the behavior of the average speed of the river. Hence this study suggests that it is not convenient to carry out estimations of icthyoplankton based on the sampling in a vertical in one of the river banks. Therefore, based on the results of the present study it can be suggested that the load of icthyoplankton is negatively correlated to the speed of the river seeing that the greater densities of icthyoplankton pass through the sedimentation margin (left) where the lesser speeds were registered. As stated previously, the speed is a variable that affects the distribution of icthyoplankton in the section of the river, which is why it is important, for the method of estimation to consider the hydraulic variables of all the points where icthyoplankton is collected from the right margin to the left.

\section{Conclusion}

Icthyoplankton is not evenly distributed in the section of the river. The distribution of icthyoplankton is intimately related to the hydraulic parameters of the bed (river). The distribution of the load of icthyoplankton inversely correlates to the speed of the river, hence why the greater loads of icthyoplankton pass through the margin of lesser speed. It is not recommendable to estimate the load of icthyoplankton from a single simple sampling in one of the river banks, as one would considerably overestimate the quantity of individuals that pass through the section of the river.

\section{Acknowledgements}

The authors would like to thank the Hidroeléctrica Urrá SA-ESP and the Universidad de Córdoba, Colombia, for the funding of this study. 


\section{Conflict of interest}

The authors declares there is no conflict of interest.

\section{References}

1. Goulding M. The fishes and the forest: Explorations in Amazonian natural history. Los Angeles: University of California press. 1980. p. 280.

2. Araujo- Lima C. Egg size and larval development in central Amazon fish. Journal of Biology. 1994;44(3):371-389.

3. Atencio VJ, Solano JM, Quirós H. Evaluación de área de desoves entre Urra I y Tierralta e identificación y cuantificación del ictioplancton. Montería (Col): Universidad de Córdoba/Urrá SA- ESP. 1996. p. 57.

4. Nakatani K, Agostinho A, Baumgartner G, et al. Ovos e larvas de peixes de agua doce: Desemvolvimiento e manual de identificao. Maringa, Eduem. 2001;378.

5. Atencio VJ. Impactos de la Hidroeléctrica Urrá en los peces migratorios del río Sinú. Temas Agrarios. 2000;8:25-40.

6. Atencio VJ, Mercado T, Quiroz H. Evaluación del desempeño reproductivo de las principales especies reofilicas en el río Sinú: Año 2001. Montería (Col): Universidad de Córdoba/Urrá Sa- ESP. 2001;90.

7. Oldani J. Identificación y morfología de larvas, juveniles y adultos de Mylossoma paraguayensis Norman 1929 (Pisces, Characidae). Studies of neotropical fauna and enviromental. 1983;18(2):89-100.

8. Araujo- lima C. A larva da branquinha común, Potamorhina latior (Curimatidae, Pisces) da Amazônia Centrale. Revista Brasileira de Biologia. 1991;51:45-56.

9. Nascimento FL, Araujo- Lima C. Descrição das larvas de Psectrogaster amazonica e Pomamorhina altmazonica (Cuirmatidae, Pisces) da Amazônia Central. Acta Amazonica. 1993;23(4):457-472.
10. Baumgartner G. Some aspects of the ecology of fish larvae in the floodplain of the high Paraná river, Brazil. Revista Brasileira de Zoologia. 1994;36.

11. Jimenez LF. Temporalidad reproductiva de los peces en la cuenca media Del rio Magdalena, Puerto Berrio (Antioquia), Colombia. Tesis Ph.D, Medellín: Universidad de Antioquia, 2007.

12. Araujo- Lima C, Oliveira EC. Transport of larva fish in the Amazon. Journal of Fish Biology. 1998;53(sA):297-306.

13. Chow V. Hidráulica de canales abiertos. Primera edición. Editorial McGRAW-HILL, Santafé de Bogotá D.C, USA; 1997.

14. Mercado T. Prácticas de hidráulica. Facultad de Ciencias Agrícolas. Universidad de Córdoba. 1995;95.

15. Mójica JI. 1999. Lista preliminar de las especies de peces dulceacuícolas de Colombia. Academia Colombiana de Ciencias 23(supl):547-566.

16. Valderrama Barco M, Salas Guzmán F, Solano Peña D. Los peces y las pesquerías en el embalse de Urrá: 2001- 2005. Montería: Boques Humedales Fundación/Empresa Urrá SA-ESP. 2006;107.

17. Pareja-Carmona M, Jímenez-Segura, Ochoa- Orrego L. 2014. Spatiotemporal variation of the larvae of three species of migratory fish in the stream bed of the Magdalena river (Colombia), during the 2006-2007 hidrological cicle. Actualidades biológicas. 2014;36(100):33-38.

18. García- Dávila C, Castro- Ruiz D, Sánchez-Ribeiro H, et al. Diversidad de ictioplancton en los ríos curaray, arabela y napo (Amazonia Peruana). Folia Amazónica. 2014;23(1):67-78.

19. Dingman SL. Physical Hydrology. Editorial Prentice- Hall; Estados Unidos de América. 1994;50.

20. De Lafontaine Y. Distribution and abundance of ichthyoplankton in the Manicouagan river estuary, a tributary of the Lower St. Lawrence estuary. Estuaries. 1990;13(1):43-50. 